\title{
Semefulness: a Social Semiotics of Touch
}

Anne Cranny-Francis

\begin{abstract}
:
This paper explores the multiple significances (semefulness) of touch, as experienced by us as embodied subjects. Prompted by the development of a range of touch-based technologies, I consider the current writings about touch in a range of fields and how these have contributed to contemporary understandings of the meanings of touch. I then explore a number of these meanings - connection, engagement, contiguity, differentiation, positioning - for their contribution to our understanding of the world and of our own embodied subjectivity. I also explore the deployment of these meanings by contemporary technologies.
\end{abstract}

\section{Keywords:}

Touch, tactility, technology, connection, engagement, contiguity, differentiation, positioning, body, embodiment, emotion, knowledge, culture

\section{Bio:}

Anne Cranny-Francis is Professor of Cultural Studies and Director of the Transforming Cultures Research Centre at the University of Technology, Sydney. She has published widely on popular fiction, film, television and multimedia, cultural theory, feminist theory, new technologies, and new literacies. Her books include MultiMedia: Text and Context (2005), Gender Studies: Terms and Debates (2003), The Body in the Text (1995), Popular Culture (1994), Engendered Fictions (1992), and Feminist Fiction (1990). Her most recent projects are: a study of the semiotics of 
touch and its deployment in new technologies, and a study of the multi-disciplinary researcher and writer, Jack Lindsay.

\section{Address:}

Professor Anne Cranny-Francis

University of Technology, Sydney (CB10.5.119)

P.O. Box 123

Broadway

NSW 2007

Australia 


\section{Semefulness: a Social Semiotics of Touch}

Anne Cranny-Francis

Touching might be described as the state whereby two entities or objects are so close that no space remains between their boundaries or surfaces; or as the process whereby a message from the brain is sent to the muscles of the hand to position itself beside or around an object or entity so that neural receptors in the skin are able to send a message back to the brain that this object or entity can be physically sensed (as on the MIT Touch Lab website). This is the physical practice and sensation of touch but this study addresses more than this; it is concerned with what that physical sensation means to individual human subjects.

Erin Manning notes that when she started writing her book, The Politics of Touch: Sense, Movement, Sovereignty "finding work on the senses was such a challenge that I welcomed anything I could lay my hands on.” (Manning 2007, xi) Since then we have seen a proliferation of writing about the senses, and some specifically on the sense of touch. This paper explores the experience of touch as sign (seme) and sensation, an embodied practice that is both culturally and socially specific and which locates us in the world in relation to other beings and objects. Accordingly, the deployment of touch reveals the nature of both embodied subjects and the society and cultures in which they live and in this sense is seme-ful - multiply significant, physically, emotionally, intellectually, spiritually, politically. Given the current proliferation of touch-based technologies, it is more than ever important to explore this semefulness. 


\section{Genealogies}

We start by mapping the current research about touch, locating its source in the development of new touch-based technologies as well as in the disciplines in which it is being produced.

\section{i. Technologies}

The development of new touch-based interfaces accompanied the spread of digital technologies in Western societies. Previously, the major impetus for touch-based technologies was the need to enable the visually-impaired to participate more fully in society (Schiff and Foulke 1982; Steffee, Suty and Delcalzo 1985; Kezuka 1997; Millar 1997; Wall and Brewster 2004; Graven 2004a, 2004b; Harrison, Grant and Conway 2004). The major form of touch technology involved in this work was haptics, which is defined by Gabriel Robles-de-la-Torre on the International Society for Haptics website as including "the study of touch capabilities in different organisms, including humans, but also the development of engineering systems to create haptic virtual environments.”. De-La-Torres’ description acknowledges the recent developments in the field of haptics research including the current proliferation of touch-based devices from games consoles to touch-screen and touch-enabled devices that are multi-sensory, deploying vision, sound and touch. At the Haptic and Audio Interaction Design Workshop in Glasgow (2006) Paul Vickers argued for a way of relating the different sensory inputs experienced by the users of multimodal displays: "When haptics are added to the mix there is a great potential for causal associations between the sound and the touch to be created in the user's mind.” Vickers notes further: "It would be instructive to look at the semiotics of hapticauditory interfaces. Whilst much has been written about the semiotics of visual and 
auditory messages less attention has been applied by semioticians to touch.” (Vickers 2006, 65) Vickers here seems to be asking for a semiotics of the sensations that constitute touch in order to relate touch to sound. While this understanding of touch is essential for the design of effective interfaces, it is not the primary concern of this paper, which addresses the social and cultural meanings of touch - and hence the meanings that may be activated by the successful interfaces envisioned by haptics engineers.

These are the meanings of touch explored by many of the designers working on the project, The Emotional Wardrobe launched at Central St Martin's College of Art and Design in 2005. According to its website the three themes were: "Emotional Connection, Human Connectedness and Customization and Creativity”. In collaboration with doctors at Imperial College one of the founder members, Lisa Stead produced a garment that "is based on the principles of affective computing and changes its aesthetics in reaction to a change in inferred emotional state. It has shown great potential for further development, which could also be used for communicative and therapeutic benefit to autistic, and deaf, dumb and blind teenagers to create inclusive emotional aesthetics.” Another member, Sharon Baurley developed interactive clothing activated by wireless signals that enabled phone users to touch each other virtually, by activating sensors in the clothing. The participants in her work reported a much greater sense of connectedness and engagement when they used this technology than with just speaking or texting (see also Baurley et al 2007). In related work communication engineer, Stephen Barrass has developed a series of projects, including Fauxy the Fake Fur with Feelings (2009), Zizi the Affectionate Couch (2003) and Pouffy the breathing Pouf (2011) to explore the interaction between 
embodied subjects and technologies that respond to human touch and/or presence. Fauxy was designed by Barrass and collaborators, Linda and Joel Davy to discover what it means to have clothing that is an extension of your own body, so that your touch is extended beyond your own physical being. Their particular concern is not what it enables the wearer to do, but what the wearer becomes. Inspired by the success of earlier projects such as ZiZi the Affectionate Couch (a fake-fur covered couch that purrs when stroked), particularly its tactile appeal to autistic children, Barrass explains:

... Fauxy will be used to explore the idea that tactile nerve extensions can connect the sensors in a smart fabric to the sensory system of the wearer

- What are the immediate sensations?

- Do the nerve extensions provide altered or augmented perception?

- Does the coat influence behaviour in some way?

- What are the effects on the scale of minutes, hours, or days?

- Is there an augmented or heightened awareness when wearing the coat?

- Can you learn to understand patterns of activity in the surroundings from these perceptions?

- If touch is one of our greatest pleasures then does the active dynamic tactility of the coat make it more pleasurable to wear? 
- Does the coat amplify or change socialization and interpersonal communication. ... (Barrass 2008, 328)

Designers, High Tea With Mrs Woo (Rowena, Juliana and Angela Foong) developed their own technologically-enhanced clothing to explore similar issues:

"It would seem that wearable technology would merely be a modification of clothing in terms of fabrication and construction, but we must ask the purpose of such a modification? Is it just another form of cultural expression in this new technological era? Or perhaps it may be considered as a shift towards a new purpose for clothing as a second skin, a means to document, analyse, understand and modify the relationship between our bodies and the environment in which we live.” (2008, 300)

I am approaching touch in a similar way, focusing on its acculturated meanings, as they are constituted through our tactile interaction with other beings and objects in our world. These meanings are potentially activated when we touch, though the nature of the particular interaction determines which meanings are deployed and to what ends. By exploring those meanings we are able to map the potentials that are available in every tactile encounter and how they might be mobilized to create the most effective and/or rich interaction.

\section{ii. Bodies}

In order to explore the meanings of the sense of touch it is useful to note the source of recent theoretical writings about touch, which developed from humanities research on 'the body'. This research has multiple sources, including feminist research on sex and 
gender (Cixous 1980; Bordo 1988; Butler 1990, 1993; Haraway 1991, 2001), poststructuralist and deconstructionist readings of the mind/body dichotomy in Western thinking and practice (Derrida 1974, 1978; Deleuze and Guattari 1983, 1986), analyses of class (Steedman 1986; Walkerdine 2001) and of race and ethnicity (Fanon 1967; Spivak 1987; Bhabha 1994) focusing on embodied perceptions of difference and practices of 'othering', disability studies exploring the 'othering' of those with different embodiment (Davis 1997; Davis and Berube 2002), cyberculture and technology studies interrogating the changes to human understandings of being generated by embodied interactions with new technologies (Balsamo 1996; Hayles 1999); performance studies analysis of the role of the body in interrogating social and cultural practice and communicating with audiences (Banes and Lepecki 2007), and so on. The most critical aspect of this work is its deconstruction of the mind/body dichotomy that structured western thinking for so long and its argument for a notion of the individual subject as an embodied being; not a transcendent brain housed in a decaying animal body (Latour, 1999).

This interrogation of bodily being accompanied the development of ethnographic methodologies in the humanities and social sciences that require researchers to be intensely, reflexively aware of the ways in which they transpose or inscribe their own responses into a research project. Initially this meant exploring how acculturated values, beliefs and attitudes might affect the researcher's analysis of and conclusions about a research subject. However, critical work on the body demonstrated that those attitudes, values and beliefs are not simply conceptual constructs or frames used in analytical thought, but are integral to the research practice because they are experienced bodily and enacted by researchers. In order to ensure that they are not 
blindly reproduced in the research design and practice, therefore, researchers need to be aware of how social and cultural discourses (attitudes, values and beliefs) have been incorporated in their own bodily responses.

David Howes' anthology, The Empire of the Senses marked the emergence of the new field of sensory studies, the purpose of which is to interrogate the ways in which the senses incorporate the values and beliefs of a culture in the individual subject.

The human sensorium ... never exists in a natural state.

Humans are social beings, and just as human nature itself is a product of culture, so is the human sensorium. ... Tastes and sounds and touches are imbued with meaning and carefully hierarchized and regulated so as to express and enforce the social and cosmic order. This system of sensory values is never entirely articulated through language, but is practiced and experienced (and sometimes challenged), by humans as culture bearers. The sensory order, in fact, is not just something one sees or hears about; it is something one lives. (Howes 2005, 3)

Sensory studies includes the work of anthropologists (Stoller 1989; Classen 1994, 2005; Howes 1991, 2003, 2005), (auto)ethnographers (Ellis 2004; Stewart 1996, 2007; Pink 2006, 2009), cultural geographers (Anderson and Gale 1992; Price and Lewis 1993; Thrift 1995, 2005, 2007) and qualitative social researchers (Lindlof and Taylor 2002; Denzin 2003; Denzin and Lincoln 2005). Its power is that it enables researchers to understand the meanings of their own sensorium and its social and cultural assumptions and allegiances, to acknowledge its role in their research 
practice, and to collaborate self-reflexively with those who may have different experience of the world.

\section{iii. Touch}

Along with work on the senses in general, a body of work is emerging that deals specifically with touch. Constance Classen's anthology, The Book of Touch is a multi-disciplinary collection, featuring work from anthropology, healthcare, aesthetics, art, dance, and literary studies. Classen writes: “Touch is not just a private act. It is a fundamental medium for the expression, experience and contestation of social values and hierarchies. The culture of touch involves all of culture. “(Classen 2005, 1) She continues:

One of the ideological barriers to writing about touch in culture is the customary Western emphasis on the brute physicality of touch. The sense of touch, like the body in general, has been positioned in opposition to the intellect, and assumed to be merely the subject of mindless pleasures and pains. (p.1)

For this reason, the critical analysis of touch only developed after feminist, poststructuralist, and postcolonial critiques of the mind/body dichotomy demonstrated the suppression of 'body' within this formulation (as noted above). Deconstructing this opposition meant that it became necessary to acknowledge and to analyse the role played by the senses in the formation of subjectivity and of knowing - not as a mechanical function controlled (processed) by the mind, but as an integral part of our negotiation of subjectivity and of our production of knowledge. 
On 16-17 May, 2008 the Courtauld Institute in London held its first conference on Sculpture and Touch in order to "to introduce a new impetus to the discussion of the relationship between touch and sculpture by setting up a dialogue between art historians and individuals with fresh insights working in disciplines beyond art history” (conference website). Just a week earlier (7 May 2008) the University College for the Creative Arts had hosted the conference and exhibition, Memory and Touch: an exploration of textural communication to explore the relationship between touch and design, noting on their website the need to explore "that level of communication achieved through attention to the senses, for "to touch is also to be touched”. And as such always creates a dialogue, a communication both before and beyond text." This description captures a critical aspect of the sense of touch; that it is at once a touching and a being touched.

For philosophers such as Michel Serres the Janus nature of touch is the source of consciousness:

I touch one of my lips with my middle finger.

Consciousness resides in this contact. I begin to examine

it. It is often hidden in a fold of tissue, lip against lip, tongue against palate, teeth touching teeth, closed eyelids, contracted sphincters, a hand clenched into a fist, fingers pressed against each other, the back of one thigh crossed over the front of the other, or one foot resting on the other. ... skin on skin becomes conscious, as does skin on mucus membrane and mucus membrane on itself. Without this folding, without the contact of the self on itself, there 
would truly be no internal self, no body properly speaking, coenesthesia even less so, no real image of the body; we would live without consciousness; slippery smooth and on the point of fading away. (Serres 2008, 22)

We know ourselves and the world through the sense of touch, crucially including our ability to touch ourselves and to make sense/meaning of that touch. At the point of touch, of contact (com- "together" + tangere "to touch"), we know both the self and the other, including the other that is also the self; that can reflect on and position the self. This is a point of connection, at which we perceive connection only through the perception of difference; otherwise all would be 'slippery smooth' continuous - the world and the self as undifferentiated. In differentiating the other from ourselves, we are able also to connect knowingly with that other.

\section{Social Semiotics}

In the rest of the paper I map the meanings of touch by reference to many of these disciplines and to the contexts in which touch is deployed. As noted earlier, this is not a study of how to generate the sensation of touch virtually - which is properly the work of engineers and multimodal analysts - but rather maps the social and cultural significances generated by the embodied experience and practice of touch. Accordingly, this might be described as a social semiotics of touch.

\section{i. Connection}

One of the fundamental properties of touch, as the Midas myth reveals, is that it creates a connection between individuals and things or other individuals. This connection is culturally determined or inflected - a function of distinctions created by 
gender, sex, class, ethnicity, religion, age, disability and so on. For example, in the 'alpha male’ world of business it is considered very disadvantageous for a man (particularly) not to shake hands firmly, in a strong, powerful (stereotypically manly) way, though a man who grips hands too firmly so that he causes pain is considered to be compensating for other weaknesses - of character or intellect (Allan and Barbara Pease 2006; Reiman 2007). Also, the touching between men and women in most cultures is finely regulated by parameters such as family relationship, work relationship, friendship, and familiarity. In western cultures, men and women touch only in the most formal way (e.g. handshake) unless they share a friendship or family connection. Those who touch too freely are regarded negatively because their touch signifies a closeness of connection that has not been established formally. And when close touching is necessitated by crowd behaviour (travel on a crowded train, for example), people conventionally pretend that the touch is not occurring; they mentally withdraw their consciousness from the touch so that they do not have to acknowledge the connection.

These meanings are specific to particular societies and cultures. So touch also connects together a culture or a society: that is, the tactile regime of a society or a culture identifies that culture and the individuals participating within it. Equally, one of the first things people need to learn in order to live comfortably within a society or culture different from that in which they grew up is its tactile regime; the consequence of failure is not only that one is rejected as alien (connection denied) but one may also seriously offend other members.

Connection between humans and other animals is also tactile - and again a range of 
parameters regulates permissible kinds of touch, such as degree of intimacy or violence (Arluke and Sanders 1996; Lockwood and Ascione 1998; Haraway 2003, 2008; Torres 2007). Again the tactile regime of each culture or society is specific. Even within the one society differences exist between urban and rural attitudes to and ways of interacting with animals, and is articulated in the tactile regime of each (rural, urban) culture. At an even more fundamental level the nature of the human is often defined in relation to 'the animal'. Western thinking conventionally demarcates the human from the animal, defining the human as 'that which is not animal'. This is incorporated into the tactile regime as the appropriateness of particular kinds of touch, so westerners are regularly less intimate and more violent in the way they touch animals than other humans.

Equally compelling is the connection established by touch between humans and things or objects. Consider this description by David Attenborough, quoted by British Museum director, Neil MacGregor, of a 1.8 million year-old stone chopping-tool:

Picking it up, your first reaction is it's very heavy, and if it's heavy of course it gives power behind your blow. The second is that it fits without any compromise into the palm of the hand, and in a position where there is a sharp edge running from my forefinger to my wrist. So I have in my hand now a sharp knife. And what is more, it's got a bulge on it so I can get a firm grip on the edge which has been chipped specially, which is sharp ... I could perfectly effectively cut meat with this. (MacGregor 2010, 11) 
MacGregor notes in Attenborough’s description “something of the excitement that [discoverer, Richard] Leakey must have felt.” (p. 11) We all know this same excitement, where the touch of an object from the past - precious to our culture or society, or even just to our own family history - links or connects us to that past. As Attenborough relates so evocatively, this happens because the same tactile regime is identified as operating in that earlier culture; the stone cutting tool that fits the hand of a human from approximately 1.8 million years ago also fits his hand. Historians and other researchers working in archives commonly report this response as they handle objects from the past - both a sense of connection between themselves and that past and a frisson or tremble (or perhaps shudder, depending on the object) that is their corporeal (tactile) response to that experience.

This connection is sometimes less comfortable when it applies to machines and particularly to the newest forms of technology. For example, the perceived deskilling and enslaving of human workers to the factory machines of the nineteenth century was expressed in their description as 'hands' (of the machine). Human interactions with technology often exhibit this contradictory tactile significance. The connection generated when the human touches the machine might constitute the human as member of a technological assemblage, from which s/he derives power; human users can feel a connection to machines and other technologies that facilitates their use, drawing them into the everyday life of the user. However, the relationship carries the same threat noted in relation to the animal - that it challenges the border between human and technology, which is another characteristic binary (human/machine) of western thinking . This unease is configured in the cyborg - the monstrous progeny of the 'unnatural' merging (connection) of human and machine, 
which has been used in science fiction since the early nineteenth century to explore the effect on human societies of the development of advanced technologies and their incorporation into everyday life.

The other source of unease comes from the question of who controls the technology with which we interact, whether this is the modern equivalent of the $19^{\text {th }}$ century factory owner, the modern commercial entrepreneur, or government agencies. In each case the concern is that users are being incorporated into a technological entity or assemblage of which they may have limited knowledge and understanding. For this reason the connection may be misleading or coercive or even dangerous for that individual - as articulated in films such as Enemy of the State (1998), The Matrix (1999) and Minority Report (2002).

So the connection, the connectedness, which is signified by touch may be useful and positive in enabling us to relate to each other, other beings and objects, and to reflexively position ourselves in the world, but where it occurs without full knowledge of the individual subject it may be harmful and disabling. This is even more critical when we consider the related meaning or significance of touch, which is engagement.

\section{ii. Engagement}

This meaning of touch encompasses the polysemy of touch as a physical, emotional and intellectual practice. Engagement, derived etymologically from the notion of a pledge or binding, captures the sense of touch as ‘being with': touching as a way of contacting - being with - physically; as a way of feeling, empathizing - being with - 
emotionally; as a way of understanding, knowing - being with - intellectually. This meaning of touch places the toucher in an intimate relation to the touched, an acceptance of 'being with' that creates the opportunity for an empathetic relationship between the two.

Touch between individuals signifies engagement when it is accompanied by other practices - visual, verbal, aural, kinesthetic - that locate the contact as intentional; unlike, for example, the contact on a crowded train that signifies connection only. Again, the related practices are culturally and socially located. So, for example, a western man engaging with a close male friend may shake hands, embrace, put his arm around his friend's shoulders - again depending on factors such as class and age - but he is extremely unlikely to walk along holding his male friend's hand. To do so in western cultures would signify that their relationship is an intimate one; that they are lovers as well as friends. On the other hand, in other cultures hand-holding between male friends does not have this meaning; it signifies friendship. Further, the touch itself is further located by cues such as conversation, movement in relation to the other person, smiling and other visual responses. In this way, participants are able to specify to their own satisfaction - and according to the tactile regimes of their society and/or culture - the engagement signified by the touch.

David Attenborough's description of holding an ancient stone chopping tool (quoted earlier) signifies not only connection but also engagement, as Attenborough traces his sense of 'being with' humans from over 1.8 million years ago. And again, archival researchers report that holding original or 'primary’ materials related to a research topic enables an engagement that informs the researcher's understanding of the 
subject not only physically, but also emotionally, intellectually and (sometimes) spiritually. Recognizing the value of this embodied practice anthropologist, Constance Classen (2005) and museologist, Fiona Candlin (2008, 2010) have recently written extensively on the role of touch in the museum, challenging the ocularcentricism of the nineteenth- and twentieth-century museum. Both Classen and Candlin quote a description by eighteenth-century writer, Sophie de la Roche of her museum experience, at a time when general access was severely limited and those who gained entry to the museum were able to touch the objects:

With what sensations one handles a Carthiginian helmet excavated near Capua, household utensils from Hercaulaneum ... There are mirrors too, belonging to Roman matrons ... with one of these mirrors in my hand I looked amongst the urns ... Nor could I restrain my desire to touch the ashes of an urn on which a female figure was being mourned. I felt it gently, with great feeling. (Candlin 2008, 11)

For de la Roche touching these objects is essential to the experience of the museum and to the experience of learning about the past. In this description she characterizes learning as a fully embodied experience: she names the provenance of the objects and describes their historical context while at the same time noting the effect on the senses and emotions of her physical proximity, her touch. In particular she relates her response to objects that she encounters in everyday life - the mirrors - and her use of them in a familiar way, establishing a line of connection between this distant past and herself. Through this contextual placement of herself - distant and different, but also similar - she creates a grounded understanding of that time and of her own. 
Similarly, she relates her emotional engagement with the ashes of a long-dead woman as creating another connection between her and the past - an emotional engagement and intensity that brings that past to life for her.

This engagement through touch with primary materials is recognized as an important aspect of the learning experience in museums. Some museums make less valuable objects or copies of objects available for handling, while others attempt to convey the experience of handling the object in other ways. For example, Isil Onol (2008) describes the Tactual Explorations Exhibition at the Northlight Gallery, Huddersfield in which ten commissioned artists presented their interpretations of a bronze bust of Sophocles. Many of these works could be explored directly tactually; others by virtual means, including a Haptic bust explored by using a Phantom Omni (Virtual Reality) device, and miniature chocolate copies of the bust that could literally or virtually be explored by the tongue. Much research continues into the development of haptic and other touch-based interfaces for use in museums, including the development of the Haptic Museum at the University of Southern California (McLaughlin et al 2000). For example, Zimmer, Jeffries and Srinivasan note of their ongoing project, 'Intimate Technologies: Touching Textiles to improve the quality of human-computer haptic (touch and feel) interaction in Material Culture’: "We are looking to a future in which technology will enable new kinds of engagement.” (Zimmer, Jeffries and Srinivasan 2008, 152) They conclude:

Getting these interfaces right requires not only the invention of new technologies but also a cultural study of the way people use technology and materials studies of possible textile surfaces that could be used as the skin of 
the display. ... Once we have a natural haptic display, we will be able to touch objects that are either too delicate or too distant to touch directly. The access provided by touch can be extremely intimate and evocative. When we have integrated touch into the digital interaction with collections and catalogues we will have fundamentally transformed visitors’ relations (both physical and web-based) with museum artefacts and between each other. (p. 158)

In their project technology is used creatively to provide the experience of direct tactile engagement, with all the physical, emotional and intellectual feedback it supplies. The authors note also that their aim includes the transformation of visitors' relations with each other, which refers to the role of touch in enabling individuals to locate or position themselves in relation to the world (discussed further below). However, we need to note also the possible negative consequences of touch, with specific reference to new technologies that exploit this meaning of touch as engagement.

Consider, for example, this description by a U.S. Army spokesman of their prototype Land Warrior uniform, a technologically-enhanced battle suit: “Armed with this technology the soldier becomes 'a totally, 100 percent integrated system ... The computer . . basically control[s] and manage[s] all the subsystems he's wearing' . . his body is transformed into a personal-area network, and becomes a node within the larger network.” (quoted in Viseu 2003, 19) This description raises serious questions about the nature of the engagement created by the soldier's wearing of this uniform and its successors. It also accords with the British Army's description of the soldier as a "biomechanical platform" (Cranny-Francis 2008). In both cases the individual 
wearing a technologically-enhanced uniform is engaged in an assemblage over which control is distributed. He (or she) has access to many applications that provide access to information and communication, as well as others that protect him/her from attack; however, others also have access to the uniform - medical staff and command staff. This begs the question of what level of control is available to the individual wearing the suit and how his/her engagement should be configured. For example, in a battle situation should we envisage a situation where the individual soldier cedes control of the assemblage to others outside the theatre of operations, offering her/his embodied understanding of events as just another input into a system/assemblage of which he/she is a node. We might argue that this has always been the role of the soldier and that this new technology has simply served to deconstruct its embodied practice. Nevertheless, the technology also offers new and different capabilities, many of which may find their way into the everyday lives of citizens.

Furthermore, the bodily touch of these technologies creates a different kind of engagement, less driven by notions of individual freedom and control and more accepting of the role of the embodied subject as a nodal point in a network - social, economic, political, cultural. The everyday equivalent is the work uniform that monitors an individual's biometrics and if the controller (either staff who monitor the devices or a set of norms coded into the uniform's electronics) decides that the individual is not working sufficiently hard or fast, sends them a message to increase their output, which is the dystopian vision of The Matrix. In these examples the ‘being with’ or engagement enabled by the touch (of the uniform) incorporates the wearer into a network that is outside her/his control, yet as noted earlier in the discussion of engagement, the nature of engagement is dependent on context. If the 
wearer cannot determine the context, then the engagement may have negative consequences (physical, emotional, intellectual) for the individual.

By contrast we might consider Cute Circuit's Hug Shirt, where the wearer is in control of the engagement. As the Cute Circuit web site explains:

Sending hugs is as easy as sending an SMS and you will be able to send hugs while you are on the move, in the same way and to the same places you are able to make phone calls (Rome to Tokyo, New York to Paris).

The system is very simple: a Hug Shirt ${ }^{\mathrm{TM}}$ (Bluetooth with sensors and actuators), a Bluetooth java enabled mobile phone with the HugMe $\mathrm{T}^{\mathrm{TM}}$ java software running (it understands what the sensors are communicating), and on the other side another phone and another shirt. If you do not have a Hug Shirt ${ }^{\mathrm{TM}}$ but know that your friend has one you can still send them a hug creating it with the HugMe ${ }^{\mathrm{TM}}$ software and it will be delivered to your friend's Hug Shirt ${ }^{\mathrm{TM}}$ !

The immediate context for the engagement, as described by the designers, includes permission from the receiver for the hug, so the engagement signified by the touch (of the Hug Shirt) is under the control of the shirt's wearer. For this reason Cute Circuit believe that users can engage productively with the Hug Shirt, using it to reinforce relationships when the owners/wearers are separated geographically because of work or illness. 
Negative responses to the Hug Shirt and similar applications concern the possible replacement of human touch - and its associated meanings - with the cold (which is to say, semiotically empty) touch of the machine; that if human users come to accept a technological hug instead of a human touch, they will lose the specificity of 'the human', effectively becoming part of a technological assemblage. Francesca Rosella of CuteCircuit approaches this concern quite differently, locating the context of the engagement - the human re-choreographing of space/time that is enabled by mobile technology, allied with evoked memories of past hugs between the participants. In this context, she argues, the human users retain control of the exchange and use the technology to enhance the human engagement signified by touch. This argument rests on an informed awareness of the technology and its capabilities, which is related to another significance of touch - contiguity.

\section{iii. Contiguity}

Touch signifies contiguity when we become aware of the boundary that separates us from others, objects, and the world around us. I am going to discuss this meaning of touch as contiguity by reference to new technologies where the notion of boundary and particularly of boundary-crossing - creates much unease.

There are two, very different approaches to the design of the user interface: one supports the minimizing, even disappearance, of (the perception of) the interface (Ishii and Ulmer 1997); the other argues for the foregrounding of the interface and its materiality (Schroeder and Rebelo 2007; Kettley 2008). For the former, success is measured by users' incorporation of the interface into their everyday lives, so they no longer consciously register it every time they use the technology. In a sense they no 
longer register the boundary between themselves and the technology and so lose the sense of contiguity. For the latter group, this loss of contiguity is potentially disempowering for the user; without a sense of boundary, they argue, users do not understand that their actions, behaviours and responses are shaped by the parameters or boundaries of the technology they are using but instead naturalize the interaction as a product of their own actions.

This accords with the notion of 'seamfulness' in technology design, derived from the work of Mark Weiser who saw the awareness of 'seams' - of the suturing of the technology into everyday life - as enabling consumers to adapt the devices to local conditions (Andersson online; Chalmers \& McColl online, Chalmers, McColl and Bell 2003; Barkhuus and Polichar 2010). It is only when we try using a wireless interface in a black spot, for example, that we are reminded that we are using an interface - when the seams show. We might modify this notion and suggest that the recognition of contiguity prompted by a seamful interface is also 'seme-ful' in that it draws the attention of users to the interface and hence to the ways in which it 'makes meanings'. So, for example, we might explore the ways in which the software we use everyday has inbuilt assumptions and protocols that delimit the ways in which we use it and so the meanings we can make.

For some designers this seamfulness is extremely important in that it also reminds users not to ignore the seme-ful possibilities of the interface itself. Franzisca Schroeder and Pedro Rebelo write eloquently about the importance of maintaining this awareness of the interface by reference to the interaction of musician and instrument: “... engaging with an instrument is seen as a transfer of information from 
one's body to the instrument, from the body to the world: the formula "from-to" mistakenly becomes of importance ... “ (p. 87). They argue instead that it is crucial that the performer/user remain aware of the instrument/interface as if it is a kind of irritant, causing them to itch and scratch:

Itching and scratching not only reveal the boundaries of one's own body, but it is also through itching and scratching that the performer is able to acknowledge strangeness and difference, as well as the resistances that are offered by her instrument. This performer/instrument environment should be conceived as one of participation and engagement, in which the instruments themselves suggest to us specific ideas of their textures and materiality. This means that the performer only becomes acquainted with the "thing" at hand by being able to test boundaries, negotiate subtleties and uncover threshold conditions. (pp. 87-88)

The 'threshold conditions' are the delimiting factors that govern the nature of the interaction enabled by the interface and they are accessed by touch - the performer's touch on the instrument, the user's touch on the keyboard, the (wearable) technology touching the body of the user. This polysemic 'touch' enables recognition of the boundary between self and other, that is both fundamental to the knowing of self and enables appreciation of the other. Schroeder and Rebelo quote the description of that touch by musician, David Moss: "when I touch the rough, textured surface of a drumskin (which was once a cow's skin!) I feel the story of time in the tiny (im)perfections, edges, ridges, and anti-gravity veins of former life (Moss 2000)” (p.88). Moss 
engages most fully with his instrument, reading both its immediate use and its history, when his touch acknowledges its materiality and its difference; when he feels the boundary between his skin and that of the drum-skin (cow-skin).

When touch is interpreted as contiguity, we become aware of the boundary between self and other and so able to locate the specificity of the other. As Schroeder and Rebelo note, without this awareness we would not have “Jimi Hendrix’s guitar feedback, John Coltrane’s unique saxophone sound or John Cage’s prepared piano” (p.90); we might have technically perfect music but it would have no soul. The delimitations of the boundary are crucial to our creative engagement. In the same way we might argue that the awareness of the boundary between ourselves and others enables the rich, delicate and creative exploration of the possible relationships between us. Further, as the supporters of seamfulness (seme-fulness) argue, this awareness of boundaries also alerts us to the conditions under which the connection takes place: that this connection is not totally under our control, but is determined by the conditions that establish the interface - whether this is the materiality of technological devices, the software programs we use, or the cultural assumptions of individual subjects.

\section{iv. Differentiation}

This is closely related to another major signification of touch - differentiation; touch signifies the difference between the self and the other, beyond the boundary. We deploy touch in this way throughout our lives, to learn about other people and other objects (Montagu 1971; Heller 1997; Paterson 2007), locating them within a network of experiences and meanings that enables us to use them effectively and to understand 
them. If we recognize the specificity of the other, then we are able to create an interaction that utilizes the full potential of that other.

Touch both connects us to technology and differentiates us from it, locating its specificity as different from our own being. As Schroeder and Rebelo write about the potential of textiles to act within a technological assemblage:

Fabrics offer a culturally rich platform for technological intervention. Let us start from the complex relationship between touch and textiles, and resist the reduction of such potentially engaging research to functional and instrumental applications. Let us think of what type of musical instrument a silk scarf might become, before incorporating a keyboard into it. (p. 90)

If we ignore the specificity of the other - person, object, material - then we will not perceive the potential it brings to an encounter and the meanings it offers. At the same time, we will not understand ourselves, as we will not have the nuanced understanding of difference to help us locate our own specificity.

Much has been written about the way that Ron Mueck’s hyperreal sculptures evoke the sense of touch: “Touch, the sense which Mueck’s rendering of warm, heavy, flesh or fine downy hair most arouses, has been deemed unreliable, dangerous or even morally questionable.” (Greeves 2003)

Image - Wild Man [insert] 
The visual contradiction that characterizes Mueck's work is the disparity between the sculptures' hyperreal surface and their size; the works are usually either very big or very small. For reasons of safety and conservation, Mueck’s relatively fragile works should not be touched by viewers and yet people crowd around the works and frequently reach out to touch or pat them. The most likely purpose of this touch is to differentiate - human from sculpture, organic from non-organic, real from non-real. Whether or not the viewer's desire is physically realized, this (impulse to) touch engages the viewer with the materiality of the sculpture, identifying how this work has been created, as well as how and why that image is not real, not-us. Effectively Mueck’s work deconstructs the mind/body split of western thinking by demonstrating that only an embodied engagement with the work - rather than a distanced reflection on it - releases its potential meanings, and the medium of that engagement is touch.

When applied to our engagement with technology, we find the same potential for deconstruction. As Schroeder and Rebelo note, we can interact reductively with technology to produce purely instrumental or functional applications. We understand technology by discerning its specificity, differentiating ourselves from it: “Technology is a mode of revealing. Technology comes to presence ... in the realm where revealing and unconcealment take place, where aletheia, truth, happens.” (Heidegger 1977, 13) The touch that differentiates is not a rejection or an othering, but a way of recognizing the truth of the other in its specificity and distinctiveness and in the same moment, of recognizing our own specificity and locatedness, our being-in the-world.

\section{v. Positioning}


Physically, touch creates an awareness of our location in space/time through embodied engagement with the world around us. The proprioceptive and vestibular senses are internal touch senses that enable us to position our bodies in space, even without visual stimuli, and to achieve equilibrium or balance. For example, sculpture occupies the same space/time continuum as its viewers, challenging them to compare their own occupation of space/time with that of the work. The monumental work tells the viewer that occupation of a large volume of space is conventionally equated with power and authority; the viewer can only see the whole work by looking up at it, in a posture associated with the acknowledgement of power and control. So the physical positioning of the viewer in relation to the work signifies also the meaning of the work within a specific culture.

Touch as a bodily sense (or set of senses - tactile, proprioceptive, vestibular) enables us to position ourselves in space/time. That positioning is always meaningful; it enacts social and cultural meanings that locate us in our world. With Ron Mueck's Wild Man (discussed above) the monumental size of the work contrasts with its subject-matter to generate a deconstruction of conventional sculpture and of our acculturated ways of seeing and knowing the world. The Wild Man of the sculpture is not a hero, but a being who is 'other' - rejected by society like the traditional Wild Man of European cultures or a contemporary vagrant - and yet Mueck’s work argues his importance to our understanding of ourselves. In his deconstructive work it is our treatment of the 'othered' rather than our praise of the successful that will stand as a monument to our society. This reading of the work demonstrates how touch signifies positioning in multiple senses - not only physically, but as an embodied practice involving also emotional, intellectual and spiritual meanings. 
This understanding of positionality is crucial for the development of a range of technologies, including wearables and locative media. For example, how is the soldier within the U.S. uniforms positioned by that technology? Is she/he already located in such a way that any rejection of directives that may be delivered to and via the technology is impossible? Can the individual inside the uniform reject an unethical order or is this technology progressively negating the distance between the individual's own moral and ethical positioning and that of those who control the technology? In our everyday lives we use various forms of locative media to find shops and restaurants and to locate our friends. To what extent does use of locative media applications already implicate us in a consumer-driven ethos that contradicts many of our stated values? And how easily do locative applications become a way of secretly tracking people? Again, is our positioning - moral, ethical - undermined by the seductive touch of this interface? The alternative is that we may use touch deconstructively to understand how we are positioned by the technologies we encounter, which reflexively makes us more aware of our own social and cultural, moral and ethical positioning.

\section{Semefulness}

Touch is seme-ful in that it is full of meanings - physical, emotional, intellectual, spiritual - and those meanings are socially and culturally specific and located. Far from being a simple, muscular response/action, touch locates us in the world, connects us to each other, and enables us to operate effectively as embodied individuals and as social subjects. By mapping some of the key meanings generated by touch - connection, engagement, contiguity, differentiation, positioning - this 
paper identifies the possibilities and problems created by the current focus on touchbased technologies - both those that deploy the user's hand (digital) touch and those that touch the body of the user. By viewing touch as a semiotic practice we can analyze our interactions - with each other, with objects (including technologies) - and so become self-aware, reflexive individuals, able to trace the determinants and consequences of our actions, for ourselves and for others.

Step One: unpick the semes. 


\section{REFERENCES}

Anderson, Kay and Fay Gale, eds. 1992. Inventing Places: studies in cultural geography. Melbourne, Australia : Longman Cheshire ; [New York] : Wiley, Halsted Press.

Andersson, Karin. 2007. Seamful Design in a Seamful Society. Paper for SIDER 2007, the 3rd Scandinavian Student Interaction Design Research Conference, Ronneby, Sweden, March 8-9, 2007.

Arluke, Arnold and Clinton R. Sanders, eds. 1996. Regarding Animals. Philadelphia: Temple University Press.

Balsamo, Anne Marie. 1996. Technologies of the Gendered Body: reading cyborg bodies. Durham: Duke University Press.

Banes, Sally and André Lepecki, ed. 2007. The Senses in Performance. NY and London: Routledge.

Barkhuus, Louise and Valerie E. Polichar. 2010. Empowerment through seamfulness: smart phones in everyday life. Published online 02 December 2010, Springer.

Barrass, Stephen. 2008. Clothing the Homunculus. Visual Communication. 7(3): 317330.

Baurley, Sharon, Philippa Brock, Erik Geelhoed, and Andrew Moore. 2007. Communication-Wear: User Feedback as Part of a Co-Design Process. Haptic and audio interaction design second international workshop, HAID 2007, Seoul, South Korea, November 29-30, 2007: Proceedings, ed. I. Oakley and S. Brewster, 56-68. Berlin and N.Y.: Springer.

Bhabha, Homi K. 1994. The Location of Culture. London and NY: Routledge. 
Bordo, Susan. 1988. Anorexia Nervosa: Psychopathology as the Crystallization of Nature. In Feminism and Foucault: Reflections on Resistance, ed. Irene Diamond and Lee Quimby, 87-118. Boston: Northeastern Univ. Press. Butler, Judith. 1990. Gender Trouble: Feminism and the Subversion of Identity. NY: Routledge.

1993. Bodies that Matter: On the Discursive Limits of "Sex". NY and London: Routledge.

Candlin, Fiona. 2008. Museums, Modernity and the Class Politics of Touching Objects. In Touch in Museums: Policy and Practice in Object Handling, ed. Helen J. Chatterjee, 9-20. Oxford and NY: Berg. 2010. Art, Museums and Touch. Manchester and NY: Manchesyer Univ. Press.

Chalmers, Matthew and Ian MacColl. n.d. Seamful and Seamless Design in Ubiquitous Computing. Glasgow: Computing Science, University of Glasgow. Online download.

Chalmers, M., I. MacColl and M. Bell. 2003. Seamful Design: Showing the Seams in Wearable Computing. Stevenage: The lnstjtution Of Electrical Engineers.

Cixous, Helene. 1980. Sorties. In New French Feminisms, ed. Elaine Marks and Isabelle de Courtivron, 90-98. Brighton, Sussex: Harvester Press.

Classen, Constance, ed. 2005. The Book of Touch. Oxford and NY: Berg. 1993. Worlds of Sense: Exploring the Senses in History and Across Cultures. London and NY: Routledge. 2005. Touch in the Museum. In The Book of Touch, ed. Constance Classen, 275-286. Oxford \& N.Y.: Berg. 
Cosgrove, Denis and Peter Jackson. 1987. New directions in cultural geography. Area 19(2): 95-101.

Cranny-Francis, Anne. 2007. Ecce techno, or, Suiting the biomechanical platform: immersion and contemporary embodiment. Visual Communication 6(2): 156169.

\section{CuteCircuit}

Davis, Lennard J. 1997. The Disability Studies Reader. NY: Routledge.

Davis, Lennard J. and Michael Berube. 2002. Bending over backwards : disability, dismodernism and other difficult positions. NY: NY Univ. Press

Deleuze, Gilles and Felix Guattari. 1983. Anti-Oedipus: Capitalism and Schizophrenia, trans. Robert Hurley, Mark Seem and Helen R. Lane. Minneapolis: University of Minnesota Press. 1987. A Thousand Plateaus: Capitalism and Schizophrenia, trans. Brian Massumi. Minneapolis: Univ. of Minnesota Press.

Denzin, Norman K. 2003. Performance Ethnography: Critical Pedagogy and the Politics of Culture. Thousand Oaks, CA : Sage.

Denzin, Norman K. and Yvonna S. Lincoln, eds. 2005. The Sage Handbook of Qualitative Research, 3rd ed. Thousand Oaks, CA: Sage.

Derrida, Jacques. 1974. Of Grammatology, trans. Gayatri Chakravorty Spivak. Baltimore and London: Johns Hopkins University Press. 1978. Writing and Difference, trans. Alan Bass. Chicago: Univ. of Chicago Press, .

Ellis, Carolyn. 2004. The Ethnographic I: A Methodological Novel about Autoethnography. Walnut Creek, CA and Oxford: AltaMira Press. 
Enemy of the State. Directed by Tony Scott. Hollywood, CA: Touchstone, 1998.

Fanon, Frantz. 1967. Black skin, white masks, trans. Charles Lam Markmann. NY: Grove Press.

Graven, T. 2004a. Aspects of Object Recognition: when touch replaces vision as the dominant sense modality. Visual Impairment Research 5 (2): 101 - 112 2004b. Recognizing Tactile representations of familiar objects: the influence of pre-cuing when touch replaces vision as the dominant sense modality. Visual Impairment Research 6 (2 - 3): 99 - 110.

Greeves, Susanna. 2003. Ron Mueck - a Redefinition of Realism. In Ron Mueck, ed Heiner Bastian, pp. 26-40. Ostfildern-Ruit: Hatje Cantz.

Haraway, Donna. 1991. Simians, Cyborgs and Women: The Reinvention of Nature, NY: Routledge.

\footnotetext{
2001. Modest_Witness@Second_Millenium.FemaleMan $@$ _Meets_OncoMouse ${ }^{\mathrm{TM}}$ : Feminism and Technoscience. NY and London: Routledge.

2003. The companion species manifesto: dogs, people, and significant otherness. Chicago: Prickly Paradigm Press.

2008. When species meet. Posthumanities series, volume 3. Minneapolis: University of Minnesota Press.

Harrison, Colin S., Mike Grant and Bernard A. Conway. 2004. Haptic Interfaces for wheelchair navigation in the built environment. Presence 13 (5): 520 - 534. Hayles, N. Katherine. 1999. How We Became Posthuman: Virtual Bodies in Cybernetics, Literature, and Informatics. Chicago: University of Chicago Press.
} 
Heidegger, Martin. 1977. The Question Concerning Technology and other essays, trans. William Lovitt. New York: Harper \& Row.

Heller, Sharon. 1997. The Vital Touch: How Intimate Contact with your Baby Leads to Happier, Healthier Development. NY: Henry Holt.

High Tea With Mrs Woo and Anne Cranny-Francis. 2008. Wear Now! Visual Communication. 7(3): 291-302.

Howes, David, ed. 1991. The Varieties of Sensory Experience: A Sourcebook in the Anthropoolgy of the Senses. Toronto: Univ. of Toronto Press. ed. 2005a. Empire of the Senses: The Sensual Culture Reader. Oxford \& NY:

Berg.

2003. Sensual Relations: Engaging the Senses in Culture and Social theory. Ann Arbor: Univ. of Michigan Press.

International Society for Haptics. What is Haptics? by Gabriel Robles-de-la-Torre. http://www.isfh.org/haptics.html

Ishii, Hiroshi and Brygg Ulmer. 1997. Tangible Bits: Towards Seamless Interfaces between People, Bits and Atoms. In Human factors in computing systems : CHI 97 conference proceedings, ed. Steven Pemberton. New York : ACM ; Harlow : Addison-Wesley.

Kettley, Sarah. 2008. Peacocks and wallflowers: (in)visibility with digital jewellery. Visual Communication 7(3): 303-316.

Kezuka, E.. 1987. The Role of Touch in Facilitated Communication. Journal of Autism and Developmental Disorders 27 (5): 571 - 593

Latour, Bruno. 2003 Do You Believe in Reality? News from the Trenches of the Science Wars? In Philosophy of Technology: The Technological Condition. 
An Anthology, ed. Robert C. Scharff and Val Dusek, 126-137. Oxford: Blackwell.

Lindlof, T. R., \& B.C. Taylor. 2002. Qualitative communication research methods, $2^{\text {nd }}$ ed. Thousand Oaks, CA: Sage Publications, Inc.

Lockwood, Randall and Frank R. Ascione. 1998. Cruelty to Animals and Interpersonal Violence: Readings in Research and Application. West Lafayette, Ind.: Purdue University Press.

MacGregor, Neil. 2010. A History of the World in 100 Objects. London: Allen Lane. McLaughlin, Margaret L., Gaurav Sukhatme, Cyrus Shahabi, Joao Hespanha, Antonio Ortega, and Gerard Medioni. n.d. The Haptic Museum. Los Angeles, CA: Integrated Media Systems Centre, University of Southern Cailornia: online download.

Manning, Erin. 2007. Politics of Touch: Sense, Movement, Sovereignty. Minneapolis and London: Univ. of Minnesota Press.

Millar, Susanna. 1997. Reading by touch. New York : Routledge.

Minority Report. Directed by Steven Spielberg. Hollywood, CA:

TCF/Dreamworks/Amblin, 2002.

Montagu, Ashley. 1971. Touching: the Human Significance of the Skin. NY: Harper \& Row.

Onol, Isil. 2008. Tactual Explorations: A Tactile Interpretation of a Musuem Exhibit through Tactile Art Works and Augmented Reality. In Touch in Museums: Policy and practice in Object Handling, ed. Helen J. Chatterjee, 91-106. Oxford and N.Y.: Berg.

Paterson, Mark. 2007. The senses of touch: haptics, affects, and technologies. Oxford and NY: Berg. 
Pease, Allan and Barbara. 2006. The Definitive Book of Body Language. NY: Bantam Dell.

Pink, Sarah. 2006. The Future of Visual Anthropology: Engaging the Senses.

Abingdon, Oxon and NY: Routledge. 2009. Doing Sensory Ethnography. London: Sage.

Price, Marie and Martin Lewis. 1993. The reinvention of cultural geography. Annals of the Association of American Geographers. 83 (1): 1-17.

Reiman, Tonya. 2007. The Power of Body Language: How to Succeed in Every Business and Social Encounter. NY: Pocket Books.

Schroeder, Franziska and Pedro Rebelo. 2007. Wearable music in engaging technologies. AI and Society 22:85-91.

Courtauld Institute, London. 2008. Sculpture and Touch. http://www.courtauld.ac.uk/researchforum/archive/2008/summer_2008.shtml

Serres, Michel. 2008. The Five Senses: A Philosophy of Mingled Bodies (I), trans. Margaret Sankey and Peter Cowley. London and NY: Continuum.

Steedman, Carolyn (1986) Landscape for a good woman: a story of two lives. Virago, London.

Steffee, Donna, Karen A. Suty, and Primo V. Delcalzo. 1985. More Than a Touch: Communicating with a blind and deaf patient. Nursing 15 (8):36-39

Stewart, Kathleen. 1996. A space on the side of the road : cultural poetics in an "other" America. Princeton : Princeton University Press.

2007. Ordinary Affects. Durham, N.C. : Duke University Press.

Stoller, Paul. 1989. The Taste of Ethnographic Things: The Senses in Anthropology. Philadelphia: Univ. of Pennsylvania Press. 
The Matrix. Directed by Larry and Andy Wachoski. Hollywood, CA: Village Roadshow/Silver, 1999.

Thrift, Nigel. 1995. Mapping the Subject: Geographies of Cultural Transformation. London and NY: Routledge.

—2005. Automobilities. London and Thousand Oaks, Calif.: Sage.

2008. Non-Representational Theory: Space, Politics, Affect. London: Routledge.

Torres, Bob. 2007. Making a Killing: The Political Economy of Animal Rights. Oakland and Edinbugh: AK Press.

University of the Arts London, Central St Martins College of Art and Design, Camberwell. The Emotional Wardrobe: http://www.emotionalwardrobe.com/ Vickers, Paul. 2006. Lemma 4: Haptic Input + Auditory Display $=$ Musical Instrument? First International Workshop, Haptic and Audio Interaction Design 2006, Glasgow UK, August/September 2006 Proceedings, ed. David McGoookin and Stephen Brewster, 56-67. Berlin and Heidelberg: SpringerVerlag.

Viseu, A. 2003. Simulation and Augmentation: Issues of Wearable Computers. Ethics and Information Technology 5(1): 17-26.

Walkerdine, Valerie. 2001. Growing up girl: psychosocial explorations of gender and class. Basingstoke: Palgrave.

Wall, S and S. Brewster. 2004. Providing External Memory Aids in Haptic Visualisations for Blind Computer Users. Proceedings of International Conference Series on Disability, Virtual Reality and Associated Technologies (ICDVRAT), New College, Oxford, UK: 20-22 
Zimmer, Robert, Janis Jeffries and Mandayam Srinivasan. 2008. Touch Technologies and Museum Access. . In Touch in Museums: Policy and practice in Object Handling, ed. Helen J. Chatterjee, 150-159. Oxford and N.Y.: Berg. 